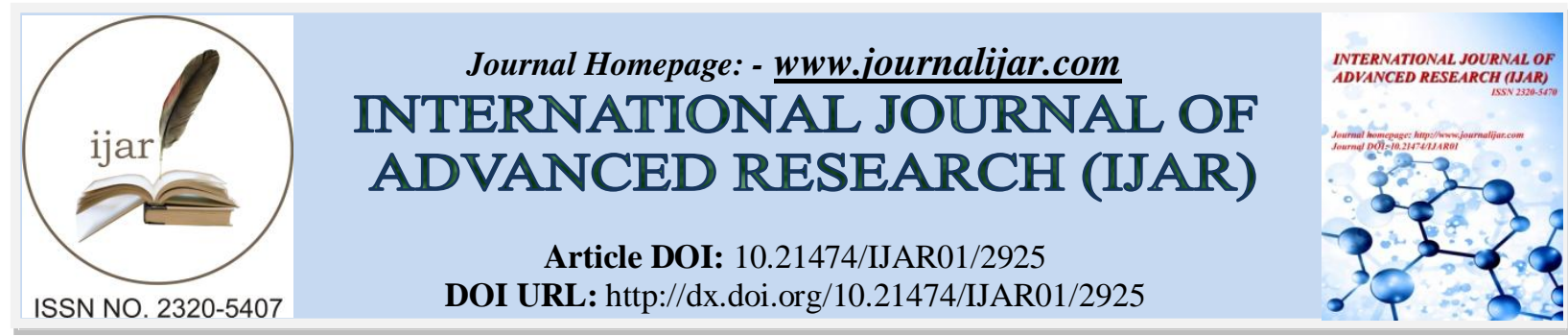

RESEARCH ARTICLE

\title{
THE ROLE OF COMMERCIAL STREETS AS A CHANNEL OF MOVEMENT IN RELATING TO THE SENSE OF PLACE
}

Musaab Sami Al-Obeidy ${ }^{1}$ and Shuhana Shamsuddin ${ }^{2}$.

1. Assistant Lecturer, Department of Architectural Engineering - Cihan University, Sulaimaniya.

2. Professor, Department of Civil Engineering (Built Environment) - University Technology Malaysia.

\section{Manuscript Info}

Manuscript History

Received: 24 November 2016

Final Accepted: 25 December 2016

Published: January 2017

Key words:-

Commercial streets, city centre, sense of place, channel of movement.

\begin{abstract}
Streets are an important part of open public spaces that reflect the character and the sense of place of cities. People depend on streets for many functional activities. One of these functions is its role as a channel of movement. Yet today, more and more streets are simply choked with car traffic vying for space with pedestrians and bicyclists. This means that priority is given to the function of the streets as a channel of movement for motor vehicles. Hence, this study tries to answer two questions. Firstly, does Nineveh Street have a role as a channel of movement in giving the sense of place to Mosul City Centre? Secondly, how do people use the street in terms of movement? The objective of the study is to examine the role of Nineveh Street in terms of movement and determine the travel mode used by people to move from one place to another in order to establish the role of Nineveh Street in giving the sense of place to Mosul City Centre in Iraq. This paper has adopted the mixed mode method. It used 330 questionnaire surveys which were designed to provide quantitative data, as well as 30 interviews and direct observation as a qualitative method.
\end{abstract}

Copy Right, IJAR, 2016,. All rights reserved.

\section{Introduction:-}

Streets are considered one of the important parts of open public spaces which reflect the character and the sense of place of cities (Najafi and Shariff, 2011). They have different functions that give them their sense of place which is reflected in the city. People use streets for their social, cultural and leisure activities, and for travel, shopping, playing and meeting other people (Abbaszadeh, 2011; Sholihah, 2006; Moughtin, 2003). Accordingly, the main objective of this research is to identify the role of one of these functional characteristics of Nineveh Street, namely movement and its contribution to the sense of place in Mosul City Centre. Understanding streets characteristics and their roles in urban studies is important to reinforce the sense of place of city centres (Cadw, 2013). Hence, this study is significant in further forming the street character of the city.

Many authors and environmental psychologists such as Steele (1981), Shamai (1991), Lynch (1981), Barker (1979), Relph (1976) believe that the experience of place is an important factor contributing to the sense of place. In this study, sense of place is defined as the qualities that differentiate between one place and another (Shamsuddin, and 
Sulaiman, 2002; Shamsuddin, et al., 2008). Therefore, the focus will be upon the qualities of the street which make it a channel of movement.

Sammas (2008) quoted from Jacobs (1961), recognised the role of streets as communication spaces, public spaces, places of social and commercial encounters and exchanges, places to do business, political spaces and symbolic and ceremonial spaces in the city. Nowadays, narrow streets accommodate old buildings, which, consequently, creates traffic congestion. For this reason, the street expansion policy has been introduced (Ja'afar et al., 2012). Besides, streets are the fundamental public space in every city, and the lifeblood of social and economic exchange. However, more and more streets are nowadays choked with car traffic vying for space with pedestrians and bicyclists. (PPS, 2012, pp.7). This means that priority is given to the function of the streets as a channel of movement for motor vehicles. Accordingly, having a central location in Mosul City, Nineveh Street is expected to be a crowded street for the movement from one place to another using various types of transportation such as cars, buses, and carts (AlJanabi, 2013). With the development of transportation modes, streets of Mosul City could not accommodate the large numbers of cars. As a result, a lot of traffic jam takes place in them.

Hence, the study addresses two questions: Firstly, does Nineveh Street have a role as a channel of movement in giving the sense of place to Mosul City Centre? Secondly, how do people use the street in terms of movements? The objective of the study is to examine the role of Nineveh Street in terms of movement and determine the travel mode used by people to move from one place to another in order to establish the role of Nineveh Street in giving the sense of place to Mosul City Centre in Iraq.

\section{Literature Review:-}

Since the present study examines the role of Nineveh commercial street, specifically its function as a channel of movement, this section explains the concept of city centre and street as one component of a city, and the role of streets as a channel of movement in relationship with sense of place.

\section{Concept of City Centre and its components:-}

Since the topic of this research refers to Mosul City Centre, it is necessary to explain the concept and definition of city centres. There are many definitions for city centre. According to Oxford (2012), a city centre defined as the central part or main business and commercial area of a city. According to Shamsuddin, et al. (2008), the street is one of the earliest components of urban spaces known to man and the most prominent 'public open space' which plays an important role especially in Asian cities. It determines the urban pattern of the cities by creating its 'sense of place'. Moughtin (2003) and Krier (1979) defined the street as one of the important elements that act as a public open space. The street acts as a medium of movement for all categories, including humans, vehicles, goods and services (Moughtin, 2003).

Depending on the predominant building use and activities taking place, streets are categorised into several types, such as civic streets, commercial streets, residential streets, pedestrian streets and a combination of commercial/residential streets (Shamsuddin and Sulaiman, 2002). This research studies Nineveh Street as one of the commercial streets in Mosul City Centre. According to many authors, commercial streets are regarded as one of the important street types. Nineveh street primarily functions as a pathway for people going from their own houses to the main square. Commercial streets, as described by Krier (1979), are by nature relatively narrower than residential streets, so that the passer-by can cast an eye over all the goods on display in the shops on the opposite side without having to cross the road. Hassan and Hamid (2010) state that commercial streets are one of the most important components of the urban system due to their facilitation of the shopping activity carried out by urban residents. Moreover, the dynamic space of a street is its formal body since it connects stable spaces which are specified by blocks on the two sides of the street. Therefore, the City Council (2003) reckons that commercial streets located in the centres should be designed to accommodate pedestrians, slow traffic, and to provide on-street parking, and create pleasant shopping environments.

\section{Streets as Channels of Movement:-}

Movement is the most important feature in determining the character of a street (Telford, 2007), and it is the main functional role of the street (Mahdzar, 2003). As a channel of movement, streets have several functions. They connect one place to another (Sholihah, 2005; Sammas, 2008). They are used by People to move from one place to another whether on foot or by cars. They provide a link between buildings, both within the street and in the city at large. They also facilitate the movement of goods (see Table 1.1). In correlation to this function, Sammas (2008) and 
Sholihah (2005) quoted from Eichner and Tobey (1987) have identified various activities regarding the use of streets as a channel of movement.

Table 1.1:- Streets as channels of movement.

\begin{tabular}{|l|}
\hline Functional Uses \\
\hline Vehicular Circulation \\
- Through movement \\
- Picking up/dropping off passengers \\
- Access to parking \\
- Buses \\
- On-street service \\
- Emergency vehicle \\
\hline Pedestrian Circulation \\
- Through movement \\
- Eaiting for, boarding and alighting from vehicles (buses, taxis, cars) \\
- Crossing streets \\
- Entering and leaving buildings \\
\hline
\end{tabular}

Source: Sholihah (2005) and Sammas (2008) quoted from Eichner and Tobey (1987).

Mahdzar (2003) affirms the importance of streets' function as a channel of movement. He states that the spatial function is performed where streets serve as a channel for urban space use or movement from one point of origin to another point of destination. Streets provide a link between buildings, both within the street, and in the city at large. They facilitate the movement of people as pedestrians or by vehicles and the movement of goods to sustain the wider market and some particular uses within the street (Moughtin, 2003, pp.130-133). What is important about a street is not only its width and the number of lanes through which one can move or the types of transportation modes used, but also what the street is linking and the kind of movement involved (Moughtin, 2003, p.130-133).

According to PPS (2008), streets are places where people walk, stroll, look, gaze, meet, play, shop and even work, but not places for cars. Although public movement involves walking, riding horses, camels and other animals, using pull carts, cycling, and driving more modern and sophisticated vehicles such as cars and motorcycles, many streets nowadays have become inundated with motorized vehicles to such an extent that the pedestrian and public life have almost been squeezed out (Sholihah, 2005; Sammas, 2008).

\section{Methodology:-}

The study adopts both quantitative and qualitative methods (see Table 1.2). The use of these methods is determined by many factors, such as the nature of the research, the research objectives, the research questions, and the methodology used in previous research. An eclectic method is used in this study because quantitative and qualitative methods each has its strengths and weaknesses, so an eclectic method helps balance out any potential weaknesses in each dada collection method (Gray, 2014).

As a quantitative method, the study relied on questionnaire surveys to examine the role of Nineveh Street in terms of movement and to determine the travel mode used by people to move from one place to another. The study used 330 questionnaire surveys based on 5.5\% sampling error at 95\% confidence level, which are employed by many considerable researchers (Shuhana 1997; Hilmilia 2005; Ja'afar, 2006; Ja'afar and Usman, 2009; Ja'afar, et al., 2012; Ujang and Dola, 2007; Ujang, 2010). A pilot survey was done before conducting the actual survey to ensure that the questions are understood by the respondents. Besides, the study made 30 semi-structured interviews, direct observations and photos as a qualitative method to measure the same street qualities measured by the quantitative method. 
Table 1.2:- Research methodology used in the study

\begin{tabular}{|c|c|c|c|}
\hline Research questions & Research objectives & Technique & Method \\
\hline \multirow{3}{*}{$\begin{array}{l}\text { Does Nineveh Street have a role } \\
\text { as a channel of movement in } \\
\text { giving the sense of place to Mosul } \\
\text { City Centre? }\end{array}$} & \multirow{3}{*}{$\begin{array}{l}\text { To examine the role of Nineveh } \\
\text { Street in terms of movement in } \\
\text { giving the sense of place to Mosul } \\
\text { City Centre. }\end{array}$} & Questionnaire & Quantitative \\
\hline & & Direct observation & Qualitative \\
\hline & & $\begin{array}{l}\text { Semi-structured } \\
\text { interviews }\end{array}$ & Qualitative \\
\hline \multirow[t]{3}{*}{$\begin{array}{l}\text { How do people use the street in } \\
\text { terms of movements? }\end{array}$} & \multirow{3}{*}{$\begin{array}{l}\text { To determine the travel mode } \\
\text { used by people from one place to } \\
\text { another. }\end{array}$} & Questionnaire & Quantitative \\
\hline & & Direct observation & Qualitative \\
\hline & & $\begin{array}{l}\text { Semi-structured } \\
\text { interviews }\end{array}$ & Qualitative \\
\hline
\end{tabular}

For questionnaire design based on reference to the previous research of Dolbani (2000) quoted from Ujang (2010), the targeted population for this study was the static and mobile users. Static users comprise shop-owners, shopkeepers, vendors, office workers, residents, and students. Mobile users comprise shoppers and visitors. Meanwhile, this study used the approach of "non-probability sampling" of "Time-interval and Cluster Sampling" (cluster sample interval), as did Hilmilia (2005) and Ja'afar (2006). In non-probability sampling, the researcher chooses the sample based on who they think would be appropriate for the study.

\section{The Study Area and Justifications:-}

Nineveh Street has been selected as the setting of the investigation of this study. It was chosen based on the functional characteristics that represent the character of Mosul City Centre after the first decade of the last century, which emerged after the British occupation of Mosul City, when the process of planning and architectural transformation occurred in these areas (see Figure 1.1). It is located within the main commercial/shopping district of the City Centre. It also receives the highest concentration of pedestrians, shoppers and visitors.

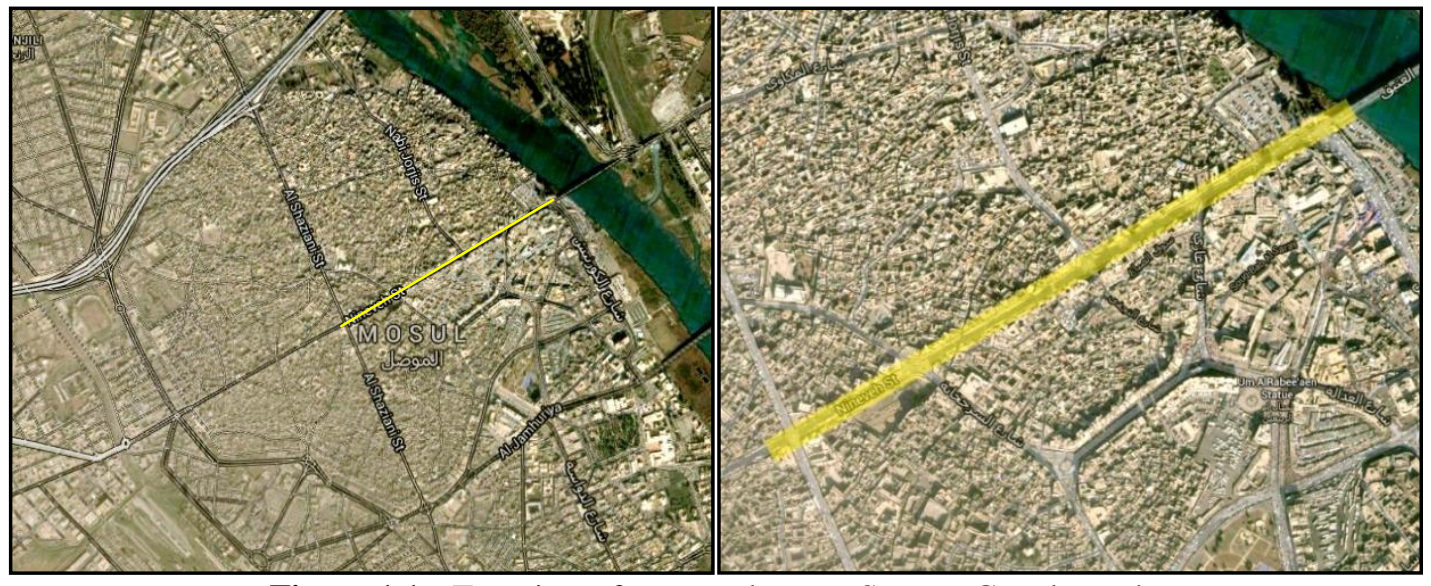

Figure 1.1:- Top view of case study area, Source: Google earth.

\section{Findings and Discussions:-}

Nineveh Street played an important role as a channel of movement. From the survey, people used the street for many purposes in terms of movement. About $63 \%(\mathrm{~N}=63)$ of the respondents mentioned that they moved from place to place accessing this Street on foot. Besides, $20 \%(\mathrm{~N}=64)$ of the respondents said that they used this Street to go to certain buildings (see Figure 1.2). The other 13\% ( $\mathrm{N}=43$ ) of the respondents used the Street to move from place to place by public transportation and $10 \%(\mathrm{~N}=33)$ used their own vehicles. In field interviews, many of the respondents explained why they used this street to move from place to place by walking. They often use this Street to go from one place to another by foot because walking is enjoyable, and closer to being a form of entertainment. In addition, this street directly connects with surrounding streets and nearby markets, which people cannot access by car. 


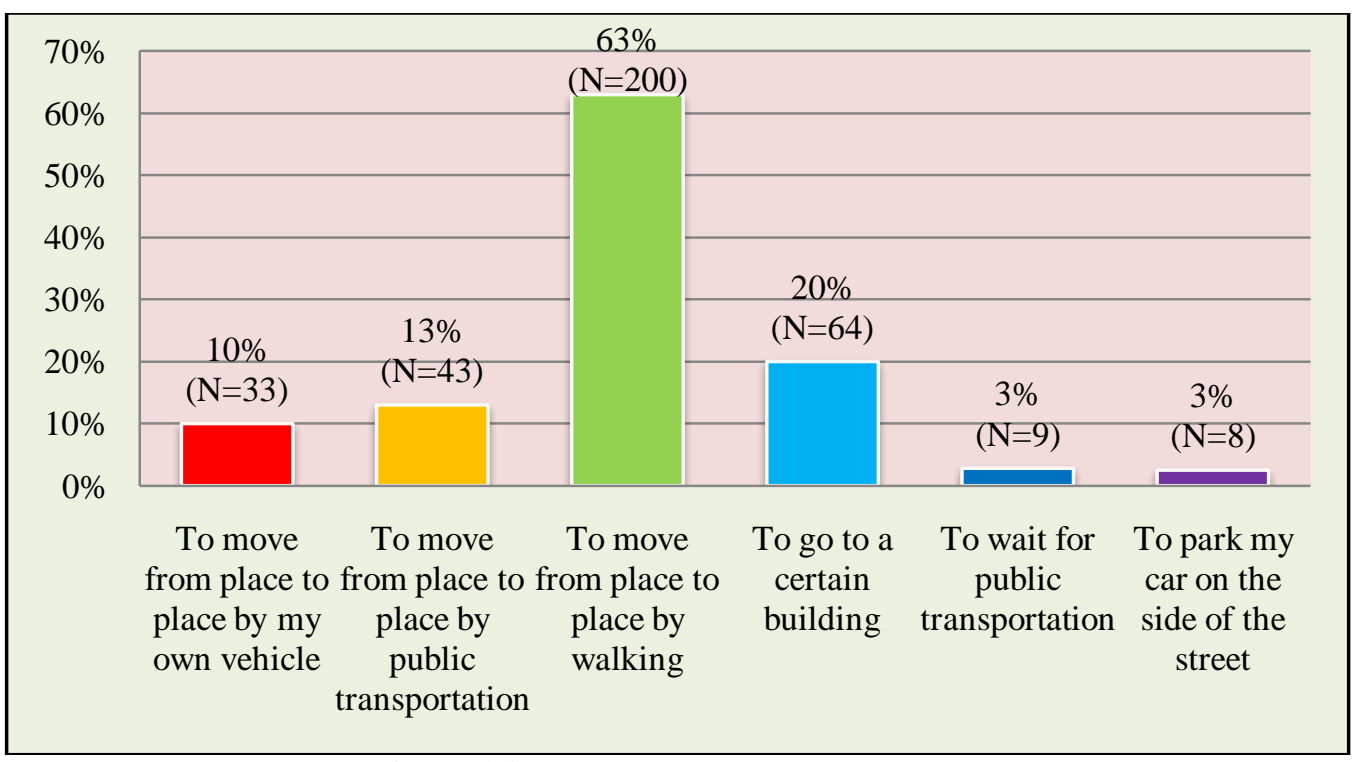

Figure 1.2:- The purpose of using the Street

The results of the survey show that Nineveh Street witnesses the arrival of a large number of respondents during daylight and as follows: $36 \%(\mathrm{~N}=114)$ respondents every day, $3 \%(\mathrm{~N}=10)$ respondents once every two days, $14 \%$ $(\mathrm{N}=44)$ respondents once a week, $4 \%(\mathrm{~N}=12)$ respondents two times a week, $10 \%(\mathrm{~N}=31)$ respondents once every two weeks, and $20 \%(\mathrm{~N}=64)$ respondents once a month (see Figure 1.3).

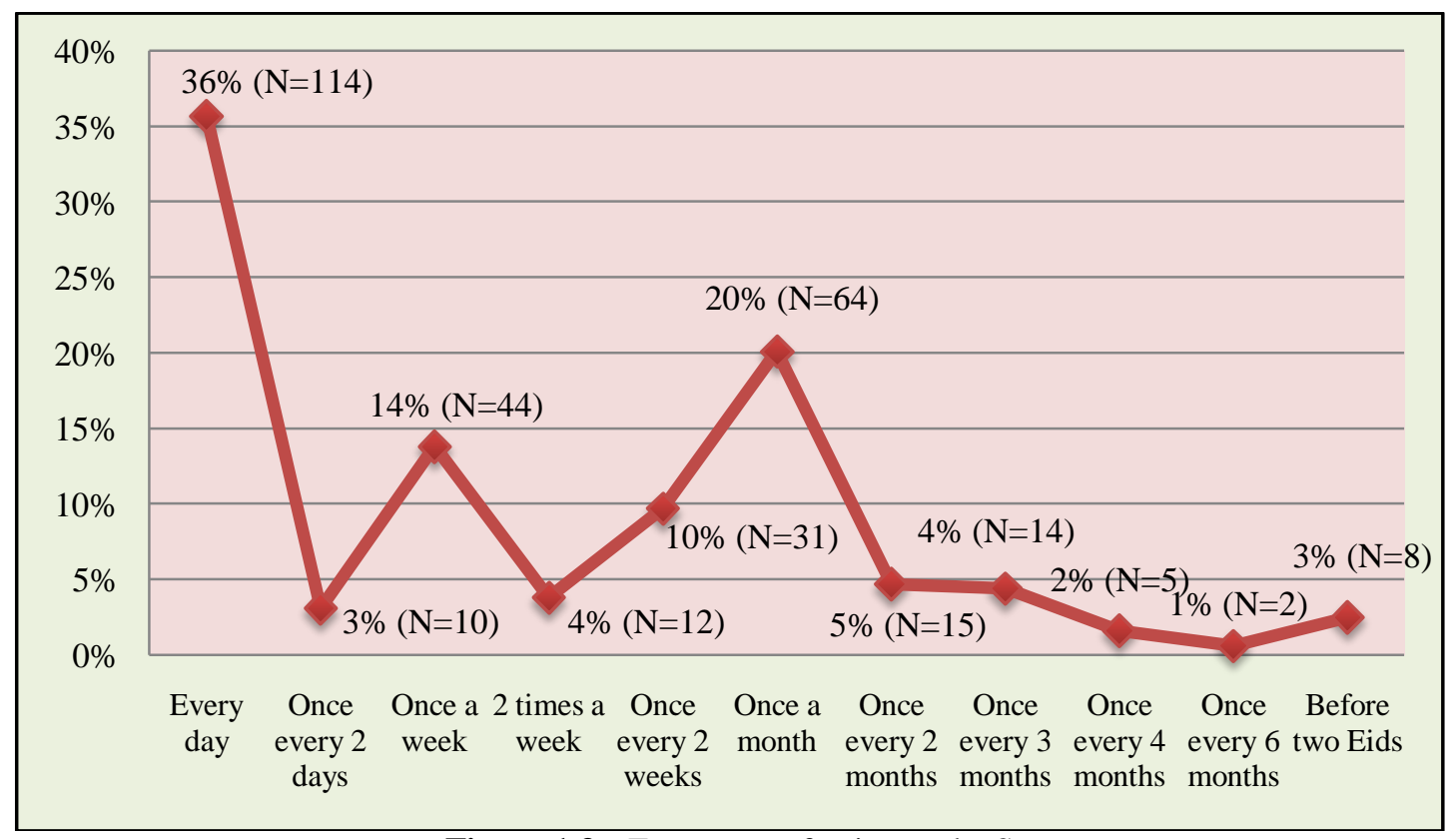

Figure 1.3:- Frequency of going to the Street

The results also show that the respondents implemented various modes of travel to reach the street from far places. The majority of them, about $47 \%(\mathrm{~N}=151)$, used public transportation (Figure 1.4). However, about 32\% ( $\mathrm{N}=101)$ of them reached the street on foot, while only $14 \%(\mathrm{~N}=46)$ of the respondents reached it by their own cars or by vans. Speed, low cost of the mode of travel and the presence of nearby public transportation stations are influential factors in people's choice of these modes of travel rather than others. 


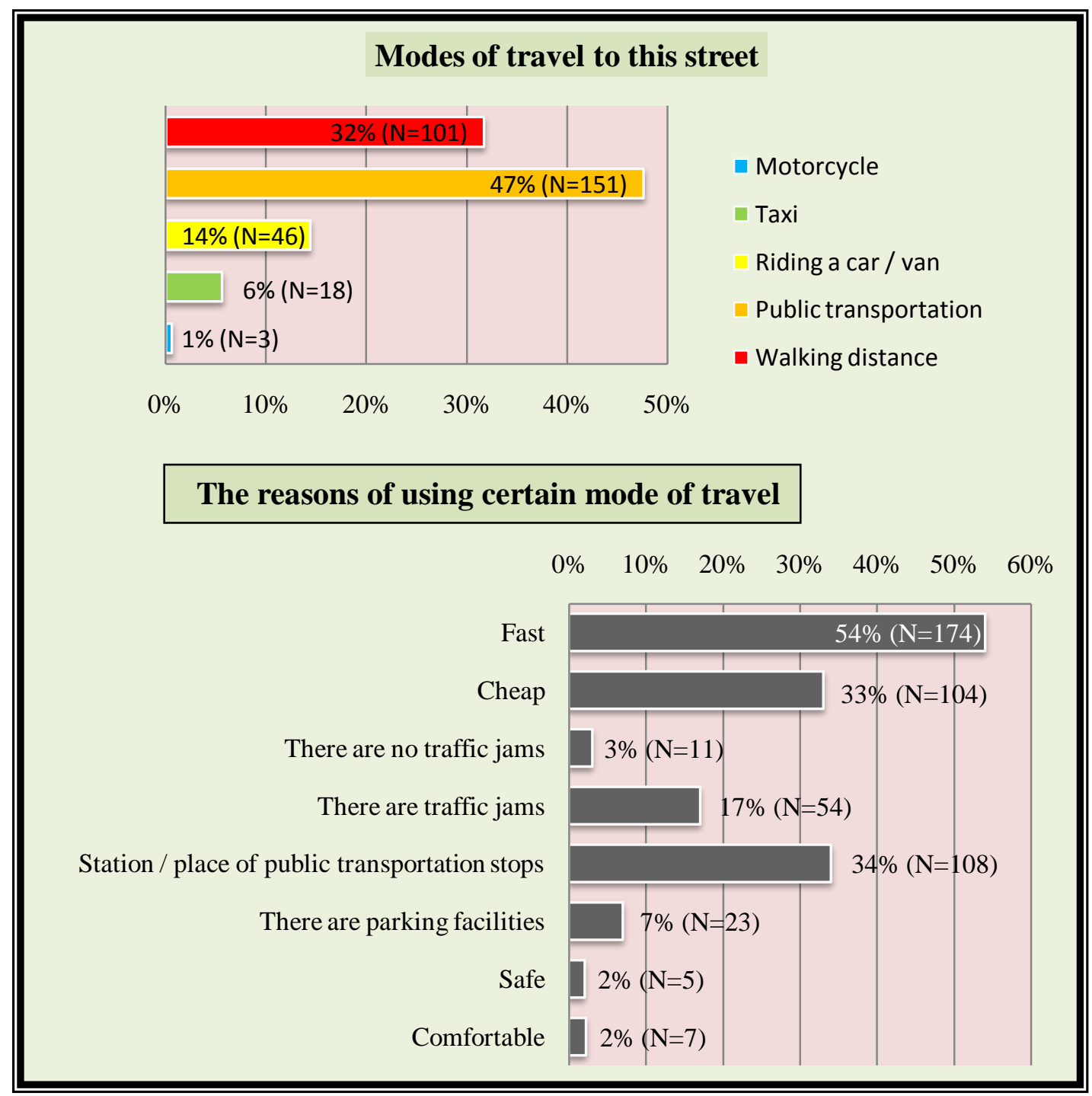

Figure 1.4:- Modes of travel to this Street from a distance and the reasons of selecting them

The survey also targeted people who were present in the street. Almost all the respondents chose walking as a mode of travel to move from one place to another (see Figure 1.5). Two striking reasons were behind people's preference of the walking mode: firstly, it is considered fast by $70 \%(\mathrm{~N}=224)$ of the respondents, and secondly, it makes it easy to understand and connect the destinations in the Street according to $51 \%(\mathrm{~N}=163)$ of the respondents. Other respondents reported cheap cost and traffic jam as reasons for preferring the walking mode to other modes of travel inside the Street. This result was also supported by many respondents who were interviewed. 


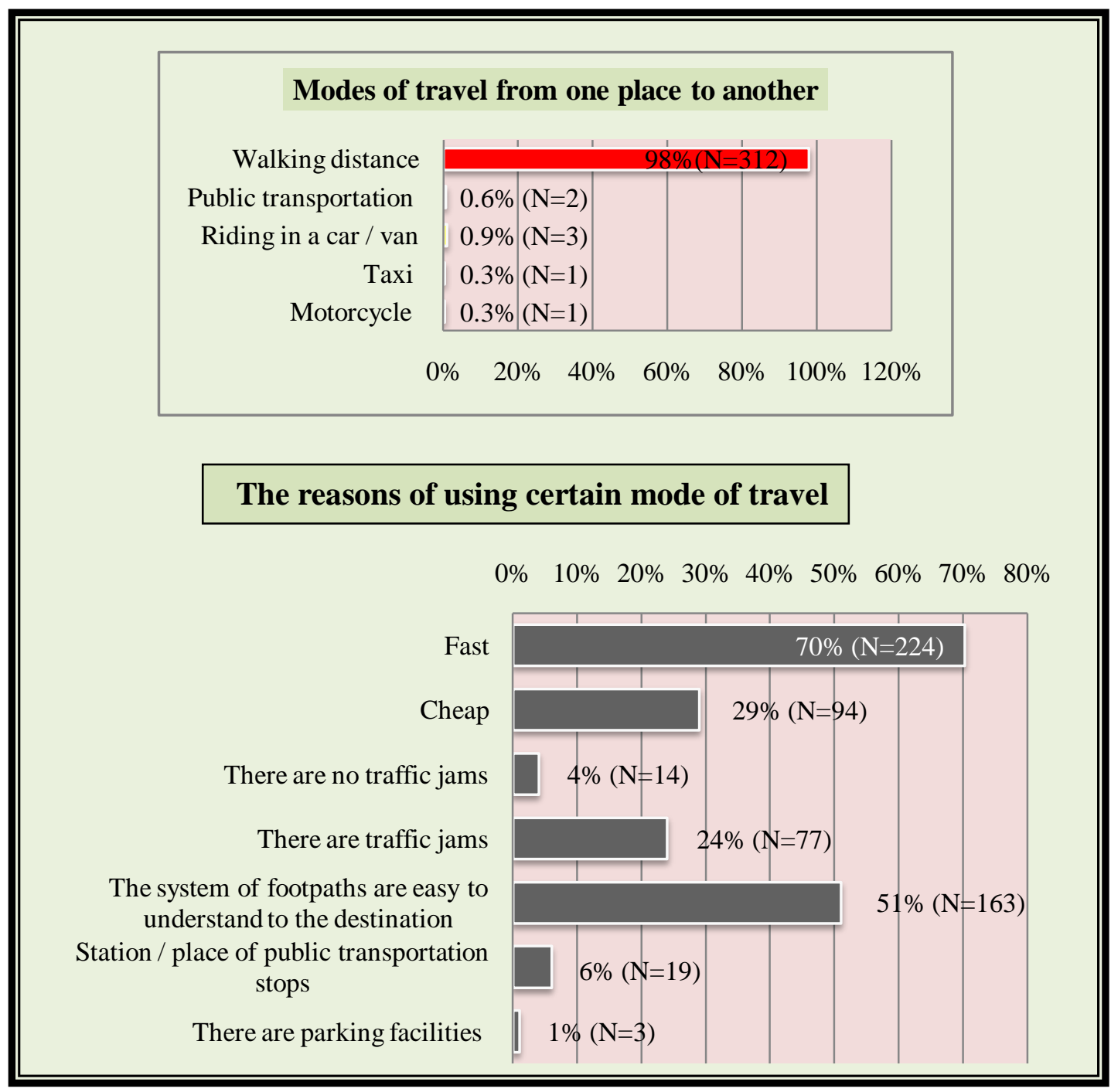

Figure 1.5:- Modes of travel used by respondents in the Street and the reasons of selecting them

The analysis of the observation photo shows that Nineveh Street is very busy during the daytime (see Figure 1.6). Due to lack of safety in Mosul City after the war in 2003, many military checkpoints have been set up in Nineveh Street and other streets. Before Eid al-Adha and Eid al-Fitr, the directorate of traffic decided to prevent vehicles from entering Nineveh Street due to the vast number of people who visit the street for shopping (see Figure 1.7).

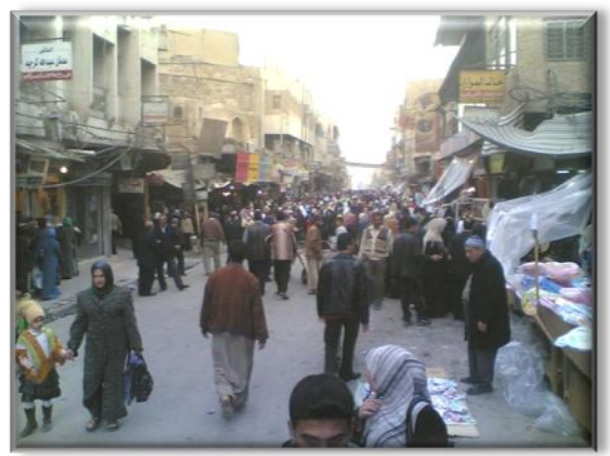

Figure 1.6:- Nineveh Street before the two Eids 
In addition, there is no doubt that the location of Nineveh Street in the core of Mosul City Centre contributes to the creation of congestion along the street, especially at the street junctions with other streets. Figure 5.41 shows the intensity of the movement of vehicles and pedestrians along the street which was observed from $9 \mathrm{am}-6: 30 \mathrm{pm}$.

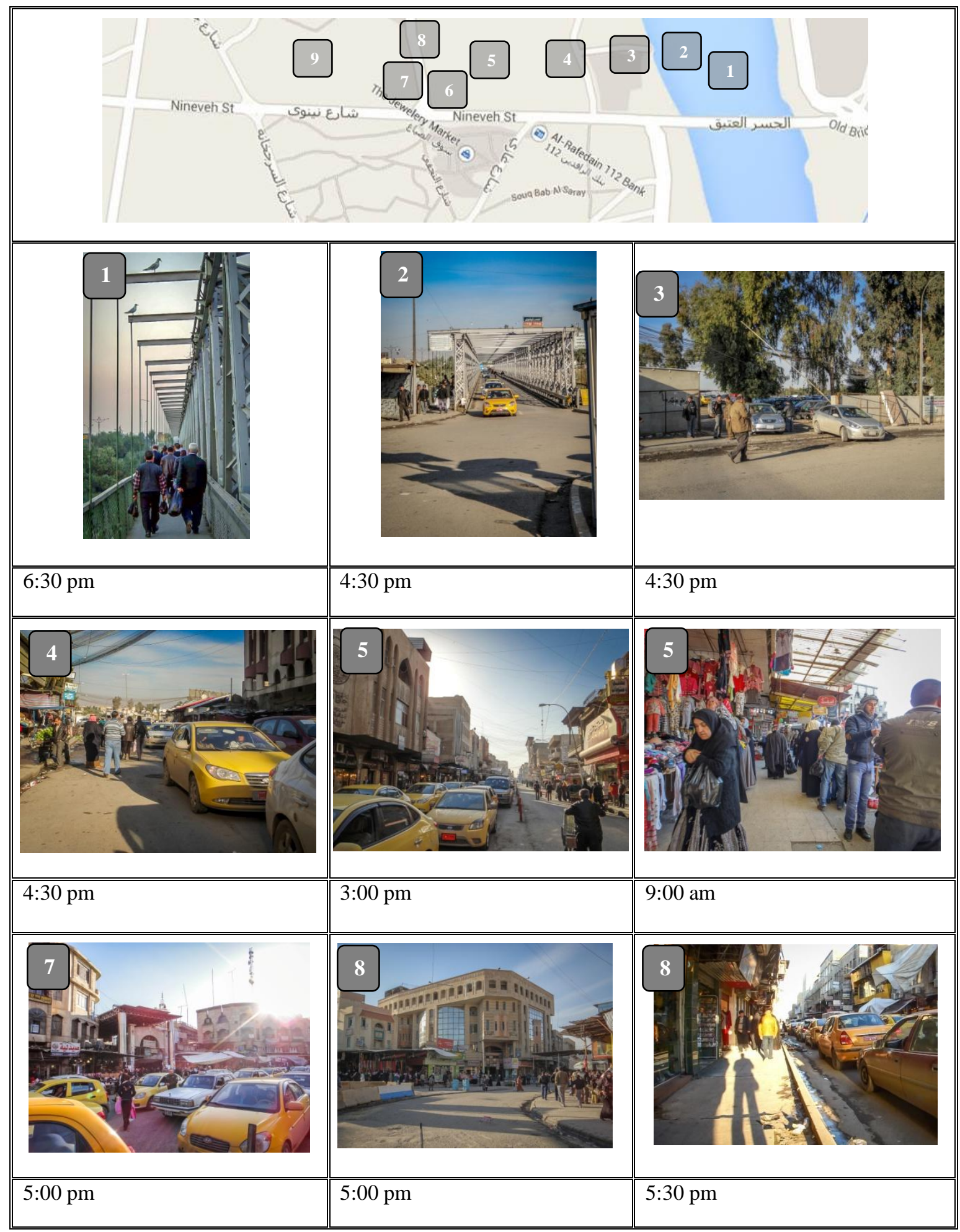

Figure 1.7:- The role of the Street as a channel of movement 
So, we can say that Nineveh Street plays an important role as a channel of movement. This result is consistent with what Ja'afar, et al. (2012) reported; however, they stated that priority is given to the function of the streets as a channel of movement for motor vehicles over other functions. Most of the respondents used Nineveh Street to move from one place to another or for other purposes in terms of movement. This was due to its location in the core of Mosul City Centre, its many links to other places, and its closeness to the public transportation area.

\section{Conclusion:-}

The study demonstrates that the role of commercial streets as a channel of movement is strongly linked to the sense of place of city centres. Nineveh Street have played effective role in relating to the sense of place as reflected in the users' high degree of dependence on the streets for movement from place to place. This is because of its strategic location in the core of Mosul city centre and overlooking the Old Bridge is considered as the gateway for users who live on the left side of Mosul City. Nevertheless, Nineveh Street misses some of its sense because of the congestion that brought about by traffic and the military checkpoints. Political issues which lead to incredible jam and effect on the role of a street as a channel of movement can also weaken sense of place of city centres. In other words, bad political conditions should be counted as one of the negative factors that reduce the importance of commercial streets in terms of serving people to move from a place to another, thus reducing the sense of place of city centres.

In addition, people move from a place to another in the street by walking more than by other modes. There is no doubt that the commercial nature of the street was the main reason that encouraged people to walk; people should walk to buy things. They cannot buy a dress, for example, while driving a car as PPS (2014) mentioned. This means that sense of place can be created by streets when they are pathways, not car roads. Meanwhile, the importance of Nineveh Street as a commercial space was stated by Al-Obeidy (2015). He argues that Nineveh Street has played a pioneer role as a commercial space due to the presence of diverse goods and shops. This means that there are relationships among street functions. Therefore, in studying commercial street roles, this study recommends studying all the functional activities together to avoid lack of information, misinterpretation, thus unconvincing results.

\section{References:-}

1. Abbaszadeh, F. A. (2011). Characterization of Physical Elements of Street Design. Unpublished PhD thesis. Universiti Teknologi Malaysia, Skudai.

2. Al-Janabi, S. (2013, May 13). Nineveh Street in Mosul: its functional importance and future. The Iraqis news agency. Retrieved on July 15, 2013, from http://iraqyoon.net/articles/news_details.php?details=459

3. Al_Obeidy, M. S., and Shamsuddin, S. (2015). Evaluating Diversity of Commercial Streets by the Approach of Sense of Place. Advances in Environmental Biology Journal. 9(4), pp. 193-196.

4. Barker, J. F. (1979). Designing for a Sense of Place in Mississippi Small Tows. Prenshaw, P. W. and McKee, J. O. (Eds). Sense of Place: Mississippi. pp:162-178. University Press of Mississippi.

5. Cadw (2013). Successful Places: A Guide to Sustainable Housing Layout and Design. (1st ed.). Crown, UK

6. City Council (2003). West Side Plan. Farmers Branch.

7. Dolbani Mijan (2000). Responsive Public Open Space In The City Centre Of Kuala Lumpur. Unpublished PhD Thesis. Oxford Brookes University, England.

8. Eichner and Tobey (1987). In Moudon, A. V. (ed). Public Streets for Public Use. Van Nostrand Reinhold Company Inc., New York.

9. Gray, D. E. (2014). Doing Research in the Real World. (4th ed). British, SAGE publication.

10. Hassan, A. A. A. R., and Hamid, L. R. (2010). Effect of Furnishing Street Space on Harmony and Consistency of Construction Environment. Al-Taqani Journal. 24(3), pp. A102-A119.

11. Himilia (2005). Apek Keselamatan Jalan Dan Kemudahan Pejalan Kaki Di Dalam Pusat Bandar Dr Perspektif Wanita: Kajian Kes Jalan Tuanku Abdul Rahman, Kuala Lumpur. Fakulti Alam Bina. Malaysia, Universiti Teknologi Malaysia.

12. Ja'afar, N. H. (2006). Criteria "Success" in the Traditional Way to Attract Visitors: Kuala Lumpur: A Case Study. Unpublished Master Thesis. Universiti Teknologi Malaysia, Skudi.

13. Ja'afar, N. H., and Sulaiman, A. B. and Shamsuddin, S. (2012). Traditional Street Activities in Kuala Lumpur City centre. International Journal of Multidisciplinary Thoughts. Volume 2 (1), p. 93-105.

14. Ja'afar, N. H. and Usman, I. M. S. (2009). Physical and Transportation Elements of Traditional Street in Malaysia. European Journal of Social Sciences. Volume 9 (4), p.669- 676. 
15. Jacob, J. (1961). The death and life of great American cities: The Failure of Modern Town Planning. London: Peregrine Books, pp. 155

16. Krier, R. (1979). Urban Space. Rizzolli International Publication, Inc.

17. Lynch, K. (1981). A Theory of Good City Form. Cambridge, MA: The MIT press. pp.118-119

18. Moughtin, C. (2003). Urban Design: Street and Square. Oxford, Butterworth, Heinemann Ltd.

19. Mahdzar, S. (2003). Sociability Vs. Accessibility: Static Pattern of Uses as New Urban Design Dimension in Measuring the Liveliness of Street Spaces in Urban Spaces. Proceedings 4th International Space Syntax Symposium London 2003, pp.101.1- 101.2.

20. Najafi, M. and Shariff, M. K. B. M. (2011). The Concept of Place and Sense of Place in Architectural Studies. International Journal of Human and Social Sciences. 6 (3), p. 187- 193

21. Oxford Dictionary (2013). Eighth edition. Oxford University Press.

22. Project for Public Spaces (PPS) (2012). Placmaking and the future of cities. Project for Public Spaces, Inc (www.pps.org).

23. Project for Public Spaces (PPS) (2014). Streets as Places: How Transportation can Create a Sense of Community. Retrieved on Nov. 1, 2013 from http://www.pps.org/

24. Project for Public Spaces (PPS) (2008). Streets as Places: Using Streets to Rebuild Communities. New York. Project for Public Spaces, Inc (www.pps.org).

25. Relphs, E. (1976). Place and Placelessness. Pion Limited, London.

26. Sammas, Y. A. A. (2008). The Role of Active Public Street as Prerequisite for Livable Cities. Unpublished Master Thesis. Universiti Teknologi Malaysia

27. Shamai, S. (1991). Sense of Place: an Empirical Measurement. Geofmm. Vol. 22 (3), PP. 347-358.

28. Shamsuddinn, S. (1997). Identity of Place: A Case Study of Kuantan Town Centre, Malaysia. Unpublished PhD thesis. University of Nottingham.

29. Shamsuddin, S., and Sulaiman, A. B. (2002). The Role of Streets in Influencing the Sense of Place of Malaysian Towns and Cities. Proceeding of Great Asian Streets Symposium: "Public Space 2002". 25-26 July 2002, Singapore. Centre for Advanced Studies in Architecture (CASA), Department Of Architecture, School of Design and Environment, National University of Singapore, 35-43

30. Shamsuddin, S., Sulaiman, A. B., and Ja'afar, N. H. (2008). The Traditional Shopping Streets and its Attractions to the Users. Sulaiman, A. B., and Mai, M. M. (eds.). Urban Design Issues in the Developing World: The Case of Malaysia and Nigeria. (1st ed.). Kuala Lumpur, Malaysia.

31. Sholihah, A. B. (2005). The Role of Informal Street Activities in the Context of Conserving Urban Cultural Entity; Case Study: Maliobro Street, Yogyakarta, Indonesia. Unpublished Master thesis. Universiti Teknologi Malaysia, Skudi.

32. Steel, F. (1981). The Sense of Place. CBI Publishing Company, Inc.

33. Telford, T. (2007). Manual for Streets. Thomas Telford Ltd. The Great Britian.

34. Ujang, N. (2010). Place Attachment and Continuity of Urban Place Identity. Asian Journal of EnvironmentBehaviour Studies. pp.61-76

35. Ujang, N. and Dola, K. (2007). Linking Activity and Place Attachment Dimensions in Enhancing the Sense of Place. Alam Cipta, International Journal on Sustainable Tropical Design Research and Practice. 2 (1). pp. 5967. ISSN 1823-7231. 